«ПЕРСПЕКТИВЫ РАЗВИТИЯ ФУНДАМЕНТАЛЬНЫХ НАУК»

\title{
HIGH TEMPERATURE AND HEAT INSULATED CALCIUM SILICATE MATERIALS
}

Yu.S. Pugovkina, A.Yu. Ostroumova, I.E. Rymanova

Scientific Supervisor: Senior Lecturer of department of Silicate and Nanomaterials Technology

V.A. Kutugin

Tomsk Polytechnic University, Russia, Tomsk, Lenin str., 30, 634050

E-mail: button_tomsk@mail.ru

\section{ВЫСОКОТЕМПЕРАТУРНЫЕ СИЛИКАТ - КАЛЬЦИЕВЫЕ ТЕПЛОИЗОЛЯЦИОННЫЕ МАТЕРИАЛЫ}

Ю.С. Пуговкина, А.Ю. Остроумова, И.Е. Рыманова

Научный руководитель: старший преподаватель кафедры ТСН В.А. Кутугин

Национальный исследовательский Томский политехнический университет,

Россия, г.Томск, пр. Ленина, 30, 634050

E-mail: button_tomsk@mail.ru

Annotation. Силикат - кальц̧иевые плиты датской фирмы «Skaтол» превосходят по всем теплоэнергетическим характеристикам отечественные материаль, но их стоимость весьма высока за счет импорта. Так как для производства подобных материалов используется дешевое и распространенное сырье, целью данной работы является исследование возможности получения силикат - кальциевых термостойких материалов на основе местного сырья. Для достижения цели были поставлены следующие задачи: 1. Исследовать образиы силикат - кальцчиевых материалов датской и китайской компаний для установления их минералогического и фазового состава; 2. Исследовать влияние состава и режима гидротермальной обработки на состав и свойства синтезируемых силикат кальичевых материалов. Промышленные образиы были исследованы методом рентгенофазового анализа и дифференциильно-сканирующей калориметрии. По результатам данных была выдвинута гипотеза разработки технологии, которая позволяет получить отечественный аналог исследуемого образия. Полученные по разработанной технологии образиьл превосходят по своим характеристикам выпускаемые в настоящее время российские материаль. Дальнейшее развитие данной технологии позволит получить сверхлегкие материалы с высокими прочностными характеристиками.

Currently heat - resistant materials, with an operating temperature of $500{ }^{\circ} \mathrm{C}$, are limited on the construction and heat-and-power insulation product market. Vermiculite slabs, mineral wool products and perlite plates can be referred to domestic materials. However, all of them have essential drawbacks. As an alternative there are Danish plates of the company «Skamol» which possess high characteristics. Production of such plates isn't presented in Russia so far and the cost of the imported materials is very high. Thereby, the purpose of our study is to research the production possibility of heat-resistant calcium silicate materials on the basis of local raw materials. To achieve the purpose the following objectives were as follows: 1. To research calcium silicate samples of Danish and Chinese companies for determination of their mineralogical and phase composition; 2 . To 
«ПЕРСПЕКТИВЫ РАЗВИТИЯ ФУНДАМЕНТАЛЬНЫХ НАУК»

research effect of the composition and mode of hydrothermal treatment on the composition and properties of the synthesized calcium silicate materials.

We began the research of industrial samples with the phase composition determination based on the X-ray diffraction analysis method (XRD). Decryption of X-ray diffraction pattern data allows us to draw a conclusion that these materials are mainly composed of calcium silicate hydrate named xonotlite. The high-temperature behavior of the material was studied on sample tiles of $10 * 10 * 2,5 \mathrm{~cm}$ in size calcinated in the blind roaster up to the temperature of $1000{ }^{\circ} \mathrm{C}$ with an exposure of two hours. Both industrial samples kept integrity and size, the mass decreased on average by $10 \%$. Subjectively, the Skamol sample is stronger than the Chinese one. In addition, the Skamol sample was researched by the method of Differential scanning calorimetry (DSC). There is a thermogram of the Skamol sample in Fig. 1. The wollastonite crystallization process is presented in terms of an insignificant exo-effect under $805^{\circ} \mathrm{C}$. [1]

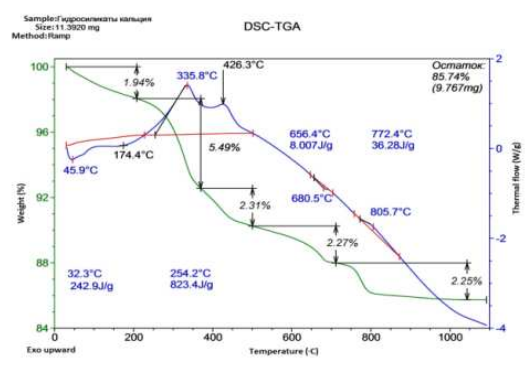

Fig. 1. Differential scanning calorimetry results of Skamol Super-Isol sample

The hypothesis of technology development was made according to the results of the conducted researches: the researched material can be obtained by means of water suspension autoclave processing prepared by intergrinding of silicic rock and lime. Based on the reaction of xonotlite production $\mathrm{Ca}(\mathrm{OH}) 2+\mathrm{SiO} 2+\mathrm{H} 2 \mathrm{O}=\mathrm{CaO} \times \mathrm{SiO} 2 \times 2 \mathrm{H} 2 \mathrm{O}$ the mixture ratio was $1: 1$. The same ratio is indicated in the specification of manufacturers. To obtain suspension of a proper consistency, some compositions with different amount of water were prepared. The received compound was dispersed in a planetary laboratory ball mill under the different modes. Fiber in the amount of $2 \%$ of mass was introduced into a part of slurry dry, then poured in metal forms (sizes of $10 * 10 * 2,5 \mathrm{~cm}$ ) and subjected to hydrothermal processing according to the modes: 16 atm.6 h. and 12 atm.6 h. The most appropriate samples were researched by XRD and DSC methods and also calcinated under $1000{ }^{\circ} \mathrm{C}$. The samples withstood calcinating without structure destruction. Results of comparative X-ray diffraction patterns of the synthesized sample under 16 atm. and the sample of Skamol are provided in Fig. 2. Crystalline perfection of sample is noted to be worse, but all the main peaks are shown on the X-ray diffraction pattern.

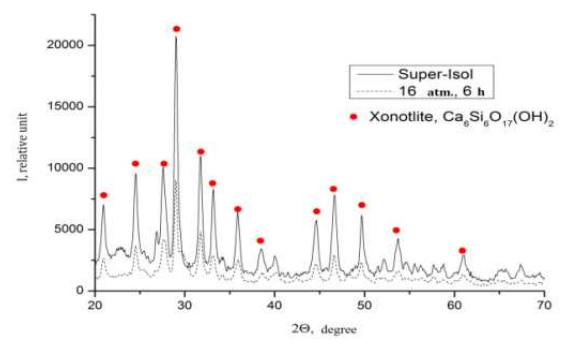

Fig. 2. XRD results of the synthesized sample under 16 atm. and Super-Isol 
«ПЕРСПЕКТИВЫ РАЗВИТИЯ ФУНДАМЕНТАЛЬНЫХ НАУК»

On comparison thermograms there is an exo-effect enhancement in the range of $800-850{ }^{\circ} \mathrm{C}$ indicating the incomplete xonotlite formation process under existing conditions that leads to wollastonite crystallization from synthesized components.

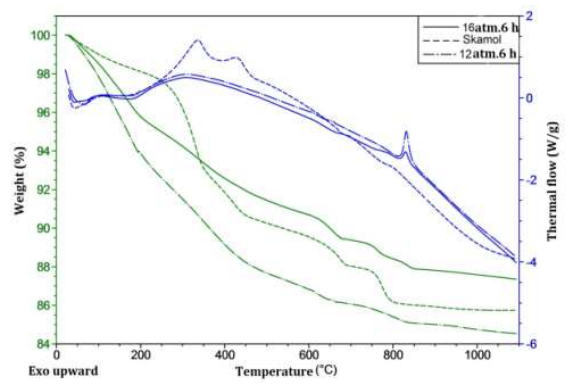

Fig. 3. Comparison thermograms of the received materials under 12 and 16 atm. and Skamol sample

Table 1

Comparison characteristics of the received samples

\begin{tabular}{|c|c|c|c|}
\hline & Density, $\mathrm{kg} / \mathrm{m} 3$ & Thermal conductivity, Vt/m·K & Strength, MPa \\
\hline Skamol & 225 & 0,076 & 2,6 \\
\hline 16 atm., composition 1 & 370 & 0,106 & 3,5 \\
\hline 16 atm., composition 5 & 310 & 0,086 & 2,9 \\
\hline 12 atm., composition 1 & 420 & 0,120 & 4,1 \\
\hline 12 atm., composition 5 & 390 & - & 3,8 \\
\hline
\end{tabular}

Based on the data we conclude that calcium silicate product synthesis should be carried out under 16 atm. with intensive grinding of raw materials. The received samples are characterized with higher density, respectively, with durability and heat conductivity. Upon heating up to $1000{ }^{\circ} \mathrm{C}$ the sizes and strength of the samples remain unchangeable.

Heat-resistant calcium silicate material obtaining based on local raw materials was studied. The samples, with significantly better characteristics than the materials produced in Russia, were received. Further technology development will allow us to produce ultralight materials with high structural characteristics.

\section{LIST OF REFERENCES}

1. Khavkin L.M. Tehnologiya silikatnogo kirpicha. - M. - 1982. - 264 c.

2. Akateva L.V. Sintez fiziko i himicheskie svoystva ksonotlita vollastonita: dis. kand. him. nauk. - Moskva. 2003. -12 c. 